\title{
The Democratic Public and the Process of Experience
}

\author{
Sebastian Bandelin \\ Faculty of Social Sciences and Philosophy, University of Marburg, Germany
}

Copyright (C) 2015 by authors, all rights reserved. Authors agree that this article remains permanently open access under the terms of the Creative Commons Attribution License 4.0 International License

\begin{abstract}
Theories of recognition are an important approach for the development and normative foundation of a critical social theory. One central thesis is here that the formation of a positive personal identity depends on the affirmation by others in contexts of mutual recognition and that this affirmation is the decisive normative criteria for the constitution of social institutions. But insofar as this personal identity is in many cases only conceived as an identification of the actor with his own qualities and abilities, it follows that the social context, in which this positive personal identity is achieved, remains arbitrary. The trouble is here that the affirmation of a certain personal identity may than correspond to the existing expectations of the actor and ensure his integrity, but at the same also reaffirm the power relations of the social context, in which this identity was formed. In the second part of my paper I would like to develop an account oriented towards the social philosophy of pragmatism, which avoids these problems. Recognizing has to be conceived not as an affirmation of an already existing identity, but as a social process. In this process the actors and social groups are always confronted with unintended social consequences of their actions for others and are therefore led to a crisis and reformulation of their actual practical identity. And this holds not only on the level of the individual, but also on that of institutions. The democratic public is the realm in which a common elucidation of problematic social consequences of the existing institutions takes place. This elucidation is then the background for a critical reflection on, and a reformulation of the guiding norms of these institutions. In consequence critique refers to blockades of this process of experience, in which institutionalized rules are questioned and reformulated.
\end{abstract}

\section{Keywords Recognition, Experience, Democracy, Pragmatism}

\section{Introduction}

With the concept of recognition Honneth tries to elaborate the normative foundations of critique and to connect given experiences of injustice and claims for respect with social movements and transformations of the whole society. I want to show in this paper that these intentions of Honneths theory can only be realized, if some of its key-concepts, especially that of practical identity, are reformulated and based on other foundations. But before I come to this, it may be helpful to structure and to summarize this complex program of a critical social theory by distinguishing the three following points:

First, Honneths theory includes a concept of social justice. The central idea here is, that the possibility of actors to achieve within their social relations a positive self-conception or a positive practical identity has to count as the central criterion to evaluate the justice or injustice of the social order in question. This positive practical identity is conceived as a result of an identification of the actor with his own wishes and abilities. I will say more about this in the following part. Second, it is said that such an identification and thereby the formation of a positive practical identity is only possible if these abilities and wishes of the actors are also affirmed or recognized by others. And this affirmation must find its expression not only in isolated acts or on the level of direct interaction but also on an institutional level (1, p57). Third, the normative development of a society is in this perspective the result of a conflict, in which social groups and movements struggle to fulfil their claims for recognition. But the claims for recognition of these social groups and movements need to be justified. And such a justification can not be based on essential features of the human nature or transhistorical norms. Rather, it has to refer to the norms of recognition, which are established within a given society. These norms, as Honneth interprets them, shape our character and whole world-view in such a deep manner, that it is nearly impossible to distance ourselves from them. They form our practical identities, the way we understand ourselves as actors. Love and the satisfaction of needs in the sphere of personal relations, respect in the sphere of formal rights and social esteem in the sphere of social division of labour can count as such norms $(2, \mathrm{p} 168)$. They define what we can legitimatly expect from others within a certain sphere of interaction. In this way, the articulation of claims has to be justified by showing that accepted norms of recognition are not fully realized within a certain context or within a certain institution. In consequence, justified critique is here always 
bound to an already existing normative consensus and it seems impossible, that it will overcome it $(3, \mathrm{p} 97)$.

In what follows, I will try to reconstruct and to criticize these three points of Honneths argumentation (2.) and to develop an alternative, inspired by the social philosophy of Hegel and its pragmatist reinterpretation (3.).

\section{Honneth's Theory of Recognition}

\subsection{Normative Reconstruction}

I will start with Honneths conception of critique. With his reconstructive or interpretative conception of critique Honneth refers to Horkheimers claim that critique should be able to conceive itself as a part of the society it describes (4, p257). From that he draws the conclusion that the normative foundations of critique can only be found in the norms which are established within the given society and accepted by the actors. According to this, critique has to show first that these norms form our self-understanding as social actors and our claims to others. Second, it has to show to what extend we realize or fail to realize these norms in our factual practice. The critical theory is then basically understood as an explication of the principles and claims which are implicitly in use in actual social conflicts and which are the basis for the justification of claims of all actors. But this argument is based on the assumption that there exists a normative consensus within the society: that all actors in fact share some basic norms on which they rely if they criticise an established practice as injustice. And this assumption can be questioned because the ability of the actors to articulate their claims depends on their social and cultural capital $(5, \mathrm{p} 154)$, because questions of social justice arise today in global contexts (6) and because the normative conceptions of different classes diverge depending on their role or function in a given social order. Different classes make different experiences corresponding to their position in a social structure and they need different belief-systems and different normative frameworks to interpret them and to articulate their claims. Thus, these conceptions also can't take into account the naturalization of social institutions, the process through which these institutions appear as natural preconditions of actions. Bur more important for me is that justified critique remains in this conception always bound to the established norms and established ways of facing a social problem and it seems impossible that it will overcome it (8). Critique is conceived here as the unfolding of an existing normative potential. And this potential is seen as the unquestionable condition of justified claims of the actors and not as a product of their collective practice.

\subsection{Recognition as Affirmation}

According to Honneth acts of recognition react on already existing evaluative qualities of the individuals $(9, \mathrm{p} 323)$. In this conception actors need to realize the evaluative qualities for which they claim recognition. Otherwise it becomes unclear how claims for recognition could be justified by practical reasons. This concept of recognition "permits us to account better for our intuition that recognition must be an act motivated by practical reasons: we thereby react in a correct or appropriate way to the reasons contained in the evaluative qualities that human beings possess in different respects." $(10, \mathrm{p} 331)$

But one problem here is that this conception can not take into account the sufferings which may arise if someone misses the requirements of the established criteria of recognizability, if someone fails to realize the qualities which are seen as valuable within a given order of recognition. This can be clarified by pointing to actual developments in the division of labour. With the marketization of the inner organization of companies workers become directly confronted with the demands of the markets (11, p34). This leads not only to an increase of internal concurrence, higher workload and pressure but also to a change of performance orientation. Within these structures market success becomes more important and this leads to a situation in which the performance and the commitment of the employees has to be proofed permanently. Their status becomes increasingly uncertain $(12, \mathrm{p} 117)$. This marketization takes place on the background of the prekarization of working-conditions. Temporary and leasing contracts are implemented in central areas of production. For companies they are means for flexible reactions to changing market conditions. But for the employees this leads to growing insecurities which undermine long-term future planing and to an increase of concurrence between different groups $(13, \mathrm{p} 52)$.

The outlined developments converge in this respect that the status of the actors within the given order of recognition becomes increasingly uncertain. The recognizability has to be proofed permanently. Who wants to achieve social esteem in the sphere of social division of labour under the conditions of prekarization and marketization needs to struggle to fulfil permanently changing criteria of recognizability. In contrast to former periods of capitalist societies achievements of the past can no longer guarantee stable forms of recognition. The status in a given order of recognition remains always precarious.

These changes in the dynamics of social conflicts reveal that criteria of recognition also determine the demands actors have to fulfil to get accepted within a given social order. In consequence, a critical reflection has to refer also to the demands these orders set as conditions of recognizability, as well as to the exclusions these conditions imply. Therefore the model of critique offered by Honneth is no longer sufficient: it is not enough to explain the normative grammar of social conflicts. Rather, a critical discussion and evaluation of basic assumptions implied in this grammar are necessary. Critique has to be conceived as critique based on these criteria of recognition as well as critique of these criteria itself. 


\subsection{Practical Identity}

I will come to the last point. To clarify the concept of a positive practical identity, the central criterion for social justice in his theory, Honneth goes back to analytical considerations about this topic, especially those of Harry G. Frankfurt (14, p327). According to this the practical identity of a person is given by her identification with her own wishes and abilities. It is an essential characteristic of human beings that they are not directly pushed by their wishes and desires, but that they are able to evaluate them, to identify with some of them and to thereby decide which ones should guide their course of action. Therefore they need some deep values, or as he calls them in other contexts "second order volutions", which are the basis of this evaluation of their wishes. "Someone has a desire of the second order either when he wants simply to have a certain desire or when he wants a certain desire to be his will. In situations of the latter kind, I shall call his second order desires "second order volutions" $[\ldots]$. Now it is having second order volutions $[\ldots]$ that I regard as essential to being a person." $(15, \mathrm{p} 8)$ These evaluations or deep values constitute the character or practical identity of an actor, which guides him in his practical decision making. The theory of recognition completes this conception by claiming that persons need the affirmation or the recognition of others to build up such stable identifications and to develop a positive practical identity. With this argument, recognition given by others and by social institutions is the necessary condition for the formation of a practical identity and for the realization of social justice, but at the same time the social relations in which the actors recognize each other have no influence on the content of that practical identity. This point needs of course some clarification. What counts as recognizable, which qualities of the actors are affirmed by others and what can therefore constitute their practical identity, is always bound to an existing normative order. Thus, the actions and qualities we estimate change with the development of social institutions. But the problem remains that this concept of practical identity is nevertheless individualistic or self-centered. This means here that the content of the practical identity of an actor is only defined by his relations to his own qualities and not by his relationship to his social environment. In this conception, recognition is in danger of being used only for instrumental reasons. Social relations and institutions can be seen by the actor only as means for his own ends: for the realization and stabilization of his own practical identity. On the other side, insofar as personal identity is in many cases only conceived as an identification of the actor with his own qualities and abilities, it follows that the social context in which this positive personal identity is achieved remains arbitrary. This is not only an abstract philosophical or historical problem. To take a concrete example: Some companies established arrangements like the "election to the worker or colleague of the month". They thereby want to compensate motivational problems of their employees and strengthen their bindings to the company, but without giving them higher salaries or more decision-making competences (16). In this case, the need to be recognized is used instrumentally: the company gives recognition, but it uses it as a means to motivate to the expected actions.

The trouble here is that the affirmation of a certain personal identity may correspond to the existing expectations of the actor and ensure his integrity, but at the same time reaffirm the power relations of the social context in which this identity was formed. As long as the actors achieve some kind of positive practical identity at all, there can be no critical discussion on the question of how and by whom it is determined who receives recognition and for what. The actors do not appear here as participants in the constitution and organization of their social relations but as needy receivers of means for their individual ends. With that Honneth's theory of recognition reflects not sufficently the dependence of the isolated individual on established criteria of recognition. Especially if we have learned from the theory of recognition how much the self-understanding of individuals and social groups depends on the recognition of others, we have to take into account that this dependence could be exploited in asymmetrical relations in which only one side defines the criteria of recognition.

I wanted to show in this part that Honneth tries to develop a critical theory of recognition which is based on legitmate norms and connected with existing experiences of social injustice and justified claims of social actors but that this conception remains at the same time insufficient because it needs to assume a shared normative consenus within a given society, because it is unable to question the established criteria of recognizability which are implied within a given normative order and because it can not take into account the various forms in which the dependence of the isolated individual on social recognition can be exploited in asymmetrical power-relations.

\section{Recognizing as Process of Experience}

In what follows I would like to outline an account which may help to overcome this dilemma and to determine social conditions of individual self-determination without masking the connection between power relations and practical identities. One central reason for the outlined problems seems to be that according to Honneths conception the normative evaluation of a social order depends on the question if it enables the actors to generate a positive practical identity and that this practical identity is conceived as a static identification with existing wishes and abilities.

\subsection{Critique and Self-reflection}

Therefore I want to shift the focus and to conceive recognizing not as an affirmation of an already existing identity, but as a social process. In this process the actors and social groups are always confronted with unintended social consequences of their actions for others and are therefore led 
to a crisis and reformulation of their actual practical identity. My plea is to locate the criteria according to which we evaluate forms of recognition within this process of conflict, mutual critique and self-reflection and that it is necessary to distinguish to levels on which this process takes place: that of direct interaction (3.1.) and that of institutionalized social praxis (3.2.). I think that some passages of the early writings of Hegel can be interpreted as a critique of an individualistic understanding of practical identity. He also has a normative ideal of mutual recognition, but it is impossible to understand this ideal by referring to the level of individualistic practical identity alone. He rather shows that the realization of a practical identity depends on the organization and creation of common relations. This becomes clear in parts of his phenomenology of spirit, in which he unfolds what he calls the "pure concept of recognition". The actors and their actions are always embedded in a shared social context. That is the reason why an action can never count only as an expression of the self-understanding of the actor; it is at the same time also the creation of a relationship to other persons. Who is engaged into practical decision making never only refers to his own desires, abilities and deep values. He must also reflect on his relations to other persons, their claims, rights, etc. This implies that every practical identity, and hence the conceptions which guide our practical decision making, include not only a concept of the own self but also a concept of the other self. "A self-consciousness exists for a self-consciousness. Only so is it fact self-consciousness; for only in this way does the unity of itself in its otherness become explicit for it." $(17, \mathrm{p} 110)$ The actor sees himself as a part in a common relation - and he sees the other as someone who sees himself also as a part in a common relation. The same idea was reformulated by John Dewey in the following way: "Each acts, insofar as the connection is known, in view of the connection. Individuals do the thinking, desiring and purposing, but what they think of is the consequences of their behavior upon that of others and that of others against themselves." $(18, \mathrm{p} 250)$ The content of practical identity is here defined by the relationship to other actors. But that means that the realization of his intentions never depends on him alone. The actor can realize his practical identity, which includes, as we saw, always a concept of his own self and those of others, only insofar as this practical identity corresponds to that of the others. The others need to interpret their relationship in the same way as he does. "Each sees the other do the same as it does; each [...] does what it does only insofar as the other does the same. [...] Thus the action has a double significance not only because it is directed against itself as well as against the other, but also because it is indivisibly the action of one as well as of the other." (17, p112)

But it cannot be taken for granted that all participants in a common relation have in fact a corresponding interpretation, that they in fact understand themselves and others in the same way as the others do. Thus it is not self-evident that there is or always will be such a shared interpretation of the common situation. But if there is no corresponding interpretation, if the actor understands her own claims, rights and duties as well as the claims, rights and duties of others differently from the others, then the realization of their practical identities fails. That means: if there is such a difference, then there will also be a difference between the intentions of the actor and the factual social consequences caused by her actions. I will call this the difference between acting and doing. But to elucidate this difference between acting and doing the actor needs the reactions and responses of the others. The other is needed to become aware of the social consequences caused by the action or of its social meaning. It is only in communication with others that we learn whether something that we did can count as the realization of our practical identities, which includes, as we saw, always a concept of our own self and those of the others, or if we missed our claims. This mutual critique is the precondition to explicate the existing action-guiding beliefs, to evaluate them and eventually to reformulate them. We cannot know what we are before we act, because we need the reactions and the critique of others to reflect upon the preconditions of our actions, especially action-guiding beliefs and dispositions. In consequence, the normative ideal of recognition has to be placed on two levels. First, its realization depends on the question of whether the actors remain open minded for such a form of mutual critique and for the questioning of their existing practical identities. Second, it depends on an institutionalization of such a process of mutual critique and the possibility of every actor to participate in this process equally.

To summarize this point: In the proposed alternative, recognition is not an affirmation of what someone actually is. Recognizing is the process in which someone learns that she did something other than she expected. No-one can know who he or she is, before he has engaged in some kind of action. The reactions of others provoked by the social consequences of an action are the condition to achieve a deeper self-understanding, and this means to achieve a critical distance towards the own action-guiding beliefs and dispositions. Hence, recognizing is not an affirmation of an already existing practical identity but the possibility to become different.

\subsection{The Democratic Public}

This logic of conflict, mutual critique and self-reflection holds not only on the level of the individual, but also on that of collective habits and institutions. Even if these institutions are established with the best intentions, no one can foresee the whole range of social consequences they may provoke. So what I called the difference between acting and doing, between the intentions of the actor and the social consequences of the action, reappears here on a higher level. It may be conceived as a practical contradiction between the ends these institutions were created for and the social reality they produce. I think that it is possible to read Deweys writings of the inter war period as an account which shows that the institutions of a capitalist society produce these kinds 
of practical contradictions.

The rise of capitalism established new forms of far reaching economical interrelations and dependence. At the present the consequences of the economic associations which determine the live conditions of all of us are suffered, but not understood and still not kept under control. This leads to growing inequalities, uncertainties and to an exclusion form effective access to the means of cultivation. "It goes, then, without saying that agencies are not established which canalize the streams of social action and thereby regulate them. Hence the [democratic] publics are amorphous and unarticulated." $(18, \mathrm{p} 317)$

On this background Dewey shows how the values of classical liberalism, the principles of negative liberty and natural rights which once contributed to the liberation from feudal bondages now serve as a mean for the justification of social inequality and economic coercion and how the norms of equality and liberty which first seem to be realized in the practice of exchange produce by the means of this realization itself their own reversal, their transition to coercion and inequality. Above all, in identifying the extension of liberty in all of its modes with the extension of their particular brand of economic liberty, they completely failed to anticipate the bearing of private control of the means of production and distribution upon the effective liberty of the masses in industry as well as in cultural goods $(19$, p29)

What follows for Dewey from this analysis of his present situation? First, we have to realize to what extend elder beliefs and principles are misleading or changed their social meaning under new circumstances. Freedom can't only be conceived as negative freedom, as the freedom to exchange products, and equality not only the juridical equality of abstract rights. Rather, it has to include the equal ability and power of every actor to contribute to the constitution of the common social relations. The concepts of freedom and equality refer then to the collective and conscious constitution of the common social relations.

The actual practical contradiction between the ends these institutions were created for and the social reality they produce has to lead to a critical reflection and reformulation of these ends itself. On the background of these experiences it becomes clear that the previously existing norms have to be reformulated. In consequence the guiding normative criteria of critique can not be bound to an already existing normative consensus or determined from the outset or in advance, they must instead be developed in this reconstruction of the existing practical contradictions. The way in which these practical contradictions are explained shows also that the structures which first seemed to be natural preconditions for the actors are in fact the product of their actions. Insofar it gives a reason and an explanation of the possibility to overcome the existing social structures. According to this the concept of social justice needs to be developed in historical experiences in which new hypothesis are build on the background of actual practical contradictions and suffering. „But to say that [...] men have been moved by what they suffer to search out new and better courses of action is to speak very veraciously.“ (20, p9) That what we mean if we talk about social justice can only be developed on the background of experiences of practical failures.

Second, we have to ask how to organize this elucidation of the existing practical contradictions between the ends the established institutions were created for and the social reality they produce on an institutional level and how to empower the actors to reorganize the institutions under which they live in consequence of such an elucidation. According to Dewey this is the task of a democratic public. In this sense the creation of a democratic public which is able to control the existing economical associations and to overcome its inequalities and coercions is still a task before us. The democratic public has to be conceived as the realm in which such a common elucidation of problematic social consequences of the existing institutions can take place. This elucidation is then the background for a critical reflection on, and a reformulation of the guiding norms of these institutions. As on the level of the individual, the reflection on social consequences is the condition for a critical distance towards the existing social norms. Such a democratic public has to give all actors the possibility to articulate how they are affected by the existing institutions and to formulate claims for a rearrangement. "The public consists of all those who are affected by the indirect consequences of transactions to such an extend that it is deemed necessary to have those consequences systematically cared for." (18, p245-46) Without such a discussion the results will be "fatally tainted with subjectivity" (21, p172). Therefore the justification of the validity claims of our social norms implies not only the freedom of speech and thought but also the abolition of economical and political inequalities which block the interests of oppressed classes form serious considerations. This includes also a strong argument against the leadership of experts well known in our present days. Because every group of experts is unable to define a common good in isolation. "There is a moral tragedy inherent in [such] efforts to further the common good which prevent the result from being either good or common - not good, because it is at the expense of the active growth of those to be helped, and not common because these have no share in bringing the results about." (22, p347)

But the creation of a democratic public requires also an end of private control of the means of production and it therefore includes the socialization of key industries, natural resources and infrastructure, redistribution and the democratization of the economy (23, p441). The scope of a democratic public can not be limited to a certain set of institutions, but it has to be expanded to all of them, especially the economy. "The idea of democracy is a wider and fuller idea than can be exemplified in the state even at its best. To be realized it must affect all modes of human association, the family, school, industry, religion." (18, p325)

Third, we have to see in general that the normative principles which form our social relations are only provisional hypotheses and are only justified if they are the 
outcome of democratic discussions and decision-making processes. This means that this ideal of recognizing refers not to a perfect set of institutions but to the possibility to correct mistakes. The normative ideal of recognition has to be conceived as a social process in which social groups are confronted with unintended social consequences of their institutions and are therefore led to a crisis and reformulation of the norms guiding these institutions. "The formation of state must be an experimental process." (18, p256)

The difference to the conception of Honneth should be clear. For him, every claim for recognition has to be justified by referring to the existing normative order. In the alternative I proposed in this paper, recognizing is the process through which the existing social norms and institutions guided by these norms are questioned and reformulated. In consequence, critique refers to blockades of this process of experience in which existing practical identities and institutionalized rules are questioned and reformulated.

\section{Conclusions}

Recognizing is the process of mutual critique which enables the actors to achieve a critical distance towards their action-guiding beliefs and dispositions. It is the possibility to become different. Blockades of experience may be conceived then as a disruption from such a common elucidation of the social consequences of established forms of action. Such a disruption occurs if some actors are excluded from the process of mutual critique and if a fixed identity is ascribed to them by others independently of their own articulations. Such a disruption occurs also if some normative rules which are embedded within a given practice and which implicitly guide the practical decision making of the actors, appear as natural preconditions of actions. An action guided by these rules remains dependent on social conditions and it contributes to the reproduction of a social structure without a conscious control of this reproduction. Recognizing is in contrast to this the process in which the reactions of others provoked by the social consequences of an action are the condition to achieve a critical distance towards the own action-guiding beliefs and dispositions. It is the process through which the existing social norms and institutions guided by these norms are questioned and reformulated. But then the realization of this ideal of mutual recognition depends on the organization of this common elucidation of the existing practical contradictions and the empowerment of the actors to reorganize the institutions under which they live. Democracy has to be conceived as a social process in which social groups are confronted with new social problems or unintended social consequences of their institutions and are therefore led to a crisis and to a common reformulation of the norms and beliefs guiding these institutions. "The end of democracy is a radical end. For it is an end that has not been adequately realized in any country at any time. It is radical because it requires great change in existing social institutions, economic, legal, and cultural." (24, pp298-99)

\section{REFERENCES}

[1] Honneth A. Pathologien des Sozialen: Tradition und Aktualität der Sozialphilosophie, in: idem. Das Andere der Gerechtigkeit. Aufsätze zur praktischen Philosophie. Frankfurt am Main: 2000.

[2] Honneth A. Umverteilung als Anerkennung: Eine Erwiderung auf Nancy Fraser, in: Honneth A. and Fraser N. Umverteilung oder Anerkennung? Eine politisch-philosophische Kontroverse. Frankfurt am Main: 2003.

[3] Boltanski L. and Honneth A. Soziologie der Kritik oder Kritische Soziologie?: Ein Gespräch mit Robin Celikates. in: Jaeggi R. and Wesche T., editors. Was ist Kritik? Frankfurt am Main: 2009.

[4] Horkheimer M. Traditionelle und kritische Theorie, in: idem., Traditionelle und kritische Theorie: Fünf Aufsätze. Frankfurt am Main: 2005.

[5] Celikates R. Kritik als soziale Praxis: Gesellschaftliche Selbstverständigung und kritische Theorie. Frankfurt am Main: 2009.

[6] O'Neil O. Starke und schwache Gesellschaftskritik in einer globalisierten Welt. in: Deutsche Zeitschrift für Philosophie, Vol. 48: 2000.

[7] Abercrombie N. and Turner B. The dominant ideology thesis. British Journal of Sociology, Vol. 29, No 2: 1978.

[8] Zurn C. Anthropology and normativity: a critique of Honneth's ,formal conception of ethical life“. in: Philosophy and Social Criticism, Vol 26: 2000.

[9] Honneth A. Kampf um Anerkennung: Zur moralischen Grammatik sozialer Konflikte. Frankfurt am Main: 1994.

[10] Honneth A. Recognition as Ideology. in: Van den Brink B. and Owen D., editors. Recognition and Power: Axel Honneth and the Tradition of Critical Social Theory. Cambridge: 2007.

[11] Glißmann W. and Peters K. Mehr Druck durch mehr Freiheit: Die neue Autonomie in der Arbeit und ihre paradoxen Folgen. Hamburg: 2001.

[12] Rosa H. Kapitalismus als Dynamisierungsspirale Soziologie als Gesellschaftskritik. in: Dörre K., Lessenich S. and Rosa H., editors. Soziologie - Kapitalismus - Kritik: Eine Debatte. Frankfurt am Main: 2009.

[13] Nies S. and Sauer D. Arbeit - mehr als Beschäftigung: Zur arbeitssoziologischen Kapitalismuskritik, in: Dörre K., Sauer D. and Wittke V., editors. Kapitalismustheorie und Arbeit: Neue Ansätze soziologischer Kritik. Frankfurt am Main: 2012.

[14] Honneth A. Kampf um Anerkennung: Zur moralischen Grammatik sozialer Konflikte. Frankfurt am Main: 1994.

[15] Frankfurt H. Freedom of the Will and the Concept of a Person, in: The Journal of Philosophy, Vol. 68, No. 1: 1971.

[16] Voswinkel S. and Wagner G. Die Vermessung von 
Anerkennung: Die Bearbeitung unsicherer Anerkennung in Organisationen. in: Honneth A., Lindemann O. and Voswinkel S., editors. Strukturwandel der Anerkennung: Paradoxien sozialer Integration in der Gegenwart. Frankfurt am Main: 2013.

[17] Hegel G.W.F. Phenomenology of spirit. Translated by A.V. Miller. Oxford: 1977.

[18] Dewey J. The Public and its Problems, in: Boydston J., editor. The Later Works $(=\mathrm{LW})$. Volume 2. Southern Illiois University: 1987.
[19] Dewey J. Liberalism and social action. in: LW. Volume 11.

[20] Dewey J. The Need for a Recovery of Philosophy, in: MW. Volume 10.

[21] Putnam H. Pragmatism and moral objectivity. in: Words and Life. Cambridge: 1995.

[22] Dewey J. Ethics. in: LW. Volume 7.

[23] Westbrook R. John Dewey and American Democracy. New York: 1991.

[24] Dewey J. Democracy is radical. in: LW. Volume 11. 